\author{
P. Sagan ${ }^{1}$, M. Frugynskyi ${ }^{2}$, R. Mroczka ${ }^{1}$, G. Wisz ${ }^{3}$
}

\title{
Properties of Multicomponent (Mn-Ni-Co-Al-Si-Ti) Oxide Spinel Hierarchically Organized Nanostructures Deposited by Magnetron Sputtering in Two Temperatures
}

\author{
${ }^{\text {I} C e n t r e ~ f o r ~ I n t e r d i s c i p l i n a r y ~ R e s e a r c h, ~ T h e ~ J o h n ~ P a u l ~ I I ~ C a t h o l i c ~ U n i v e r s i t y ~ o f ~ L u b l i n, ~ L u b l i n, ~ P o l a n d, ~ p i o t r . s . l u b l i n @ g m a i l . c o m ~}$ \\ ${ }^{2}$ National University "Lviv Polytechnic", Lviv, Ukraine \\ ${ }^{3}$ Department of Experimental Physics, Faculty of Mathematics and Natural Sciences, University of Rzeszow, Rzeszow, Poland, \\ gwisz@ur.edu.pl
}

\begin{abstract}
Multicomponent spinel films were deposited on $\mathrm{Ag} / \mathrm{Si}$ substrates by magnetron sputtering. Two substrate temperatures were used. XRD diffraction measurements show that the layers are composed of three metals oxides $\left(\mathrm{Mn}_{2} \mathrm{O}_{3}, \mathrm{NiO}, \mathrm{CoO}\right)$. The presence of spinel phase is poorly visible. However, electron diffraction measurements (RHEED) clearly confirmed the presence of nanostructured spinel structure on top of the samples. Moreover, AFM measurements show that nanostructured spinel islands are present on the sample surface. The measurements validated that indeed, hierarchically organized spinel-oxides nanostructures were obtained. A possible model growth of the spinel nanostructures at different temperatures is discussed.

Keywords: magnetron sputtering, films, hierarchical structure, spinel oxides.
\end{abstract}

Received 23 August2021; Accepted 09 September 2021.

\section{Introduction}

In designing, synthesis and productions of new, functional materials, the control of their structure on the nanometer level (nanoscale) has a crucial importance. Theses hierarchical structures are composed of elements belonging to different scales, mainly organized in such a way, that the larger elements contain smaller ones [1]. In this case, it is possible to develop functional materials with various properties using one technology, in which the control of the composition, morphology and structure of the sub-elements, on one or several levels, is realized by self-organizing processes. The obtained nanomaterials or hierarchical structures are widely applied in practice in different areas, such as production and energy storage [2], environmental sciences and environment protection $[3,4]$, catalysis [5] etc.

Multicomponent oxides are currently used for producing a variety of highly efficient sensors $[6,7,8]$ and photoelectric elements [9]. In the last years they were also thought as perspective materials for applications in spin-dependent electronics, which utilizes both charge and spin degrees of freedom of carriers for realization of their functionalities [10, 11]. Spintronic devices should be realized thin films on silicon substrates to ensure their compatibility with classical electronics.

Spinels, based on the oxides of transitional 3d-metals, are assumed to be appropriate for this purpose. Proper choice of the components and their ratio is of main importance to develop dilute magnetic semiconductors (DMS) exhibiting ferromagnetic properties up to above the room temperature (RT). We consider a quinary oxide spinel: $\left(\mathrm{MnAl}_{2} \mathrm{O}_{4}\right)_{0.05}\left(\mathrm{NiMn}_{2} \mathrm{O}_{4}\right)_{0.6}\left(\mathrm{Co}_{2} \mathrm{SiO}_{4}\right)_{0.05}\left(\mathrm{Co}_{2} \mathrm{TiO}_{4}\right)_{0.1}(\mathrm{Mn}$ $\left.\mathrm{Co}_{2} \mathrm{O}_{4}\right)_{0.2}$ as a model system for the investigations.

Herein multicomponent spinel films were deposited on $\mathrm{Ag} / \mathrm{Si}$ substates by $\mathrm{RF}$ magnetron sputtering at two substrate temperatures. We report for the first time the growth of multiphase hierarchical nanostructures independently from the substrate temperature. The influence of the substrate temperature is also discussed. 


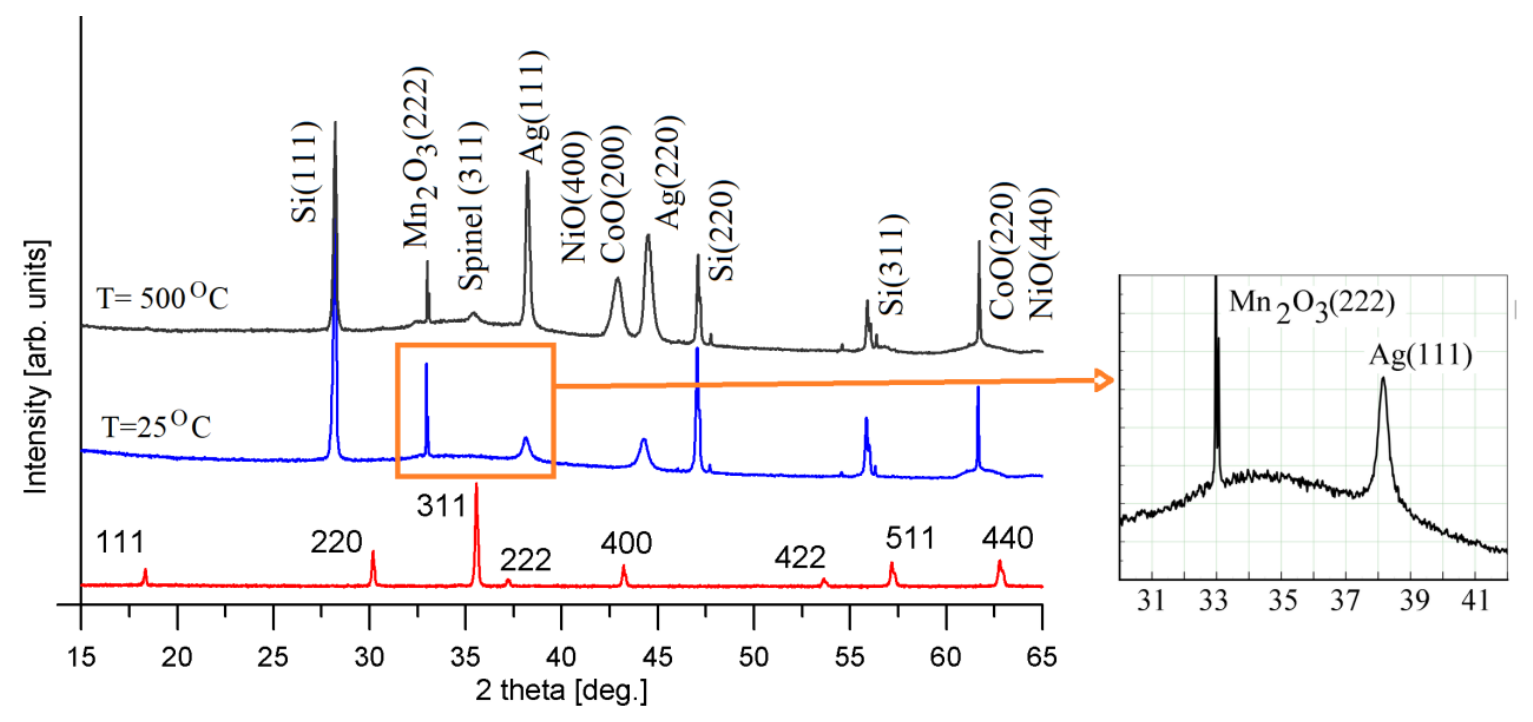

Fig 1. XRD Diffractograms obtained from of the target and the films deposited in two temperatures showing the presence of a nanostructured spinel phase.

\section{Experimental}

The target (polycrystalline single-phase solid solution $\left(\mathrm{MnAl}_{2} \mathrm{O}_{4}\right)_{0.05}\left(\mathrm{NiMn}_{2} \mathrm{O}_{4}\right)_{0.6}\left(\mathrm{Co}_{2} \mathrm{SiO}_{4}\right)_{0.05}\left(\mathrm{Co}_{2} \mathrm{TiO}_{4}\right)_{0.1}(\mathrm{Mn}$ $\left.\mathrm{Co}_{2} \mathrm{O}_{4}\right)_{0.2}$ ) was prepared by typical ceramic technology (isothermal annealing at $1100{ }^{\circ} \mathrm{C}$ for 1 hour). For synthesis carbonic salts and oxides with purity higher than $99.9 \%\left(\mathrm{NiCO}_{3}, \mathrm{MnCO}_{3}, \mathrm{CoCO}_{3}, \mathrm{Al}_{2} \mathrm{O}_{3} \mathrm{TiO}_{2}, \mathrm{SiO}_{2}\right)$ were used.

Layers of complex oxides were obtained using a sputtering system with a magnetron power unit power of $8 \mathrm{~W} / \mathrm{cm}^{2}$ during $50 \mathrm{~min}$. The substrate temperature during the deposition was room temperature (RT) and $500{ }^{\circ} \mathrm{C}$. The thicknesses of the films were $180 \mathrm{~nm}$ and $340 \mathrm{~nm}$, respectively. As substrates $100 \mathrm{~nm}$ thick Ag layers deposited on $\mathrm{Si}(001)$ silicon wafer were used. The gas pressure (Ar) in the chamber during sputtering was $0.9 \mathrm{~Pa}$.

A Pananalitycal X-pert diffractometer with a $\mathrm{Cu}$ lamp and a wavelength of $1.541 \mathrm{~A}$ was used to obtain XRD diffractograms. A Tescan Vega LMU scanning electron microscope equipped with an energy dispersive $\mathrm{X}$-ray spectrometer (EDS) from Oxford Instruments with Inca software was used to image the surface topography and determine the composition of the target and layers and target. The thickness of the layers was measured with a Dektak mechanical profilometer. The AFM images were obtained by LS5600 (Agilent) atomic force microscope. Electron diffraction patterns were obtained by AK-100 electron diffractometer with working voltage of $80 \mathrm{kV}$.

\section{Results}

\subsection{Structural analysis by $X$-ray diffraction}

The XRD diffractograms obtained from spinel films and the target are presented in Fig. 1. In the target diffractogram eight diffraction peaks, which are characteristic for the spinel structure (111), (220), (311), (222), (400), (422), (511), (440) are visible. The lattice constant of the target material calculated from data obtained with XRD diffractogram is $8.367 \AA$. The XRD diffractogram obtained from the target confirms its crystalline nature. On the diffractograms obtained from the films, diffraction peaks, which are characteristic for the used substrate: $\mathrm{Si}$ and Ag have the highest intensity. However, also peaks corresponding to the three oxides: manganese oxide $\mathrm{Mn}_{2} \mathrm{O}_{3}$ (cubic, $\mathrm{a}_{\mathrm{o}}=9.412 \AA$ ), cobalt oxide CoO (cubic, halite $\mathrm{a}_{\mathrm{o}}=4.250 \AA$ ) and nickel oxide $\mathrm{NiO}$ (cubic, halite $\mathrm{a}_{\mathrm{o}}=4.194 \AA$ ) are observed. Moreover, the spinel phase in the films could be identified by XRD diffraction. For the sample deposited at RT, a small bulge is visible in the diffractogram, inset in Fig, 1, and for the sample deposited at higher temperature a small peak located at position corresponding to the (311) plane measured in the target, Fig. 1. The broad and low intensity diffraction peaks strongly suggest that only a very small amount of nanostructured spinel is present in the samples. The intensity of the (311) peak for the film deposited at higher temperature, shows that this film is much better crystalized and oriented compared to the one grown at RT as the film thickness increases.

\subsection{Morphology analysis by Scanning Electron} Microscopy

The topographies of film surfaces are presented in Fig 2. The surface of the film deposited at room temperature is flat and smooth. Crystallites with sizes below $100 \mathrm{~nm}$ are weakly visible. The topography of the film deposited at high temperature is quite different. The surface is not smooth and clearly structured, A few big (700 nm approx.) and many smaller (100 nm - $300 \mathrm{~nm})$ crystallites are visible.

\subsection{Morphology analysis by Atomic Force} Microscopy (AFM)

The surface of the silver film deposited on Si used as substrate for spinel film growth is presented on Fig 3a. It 


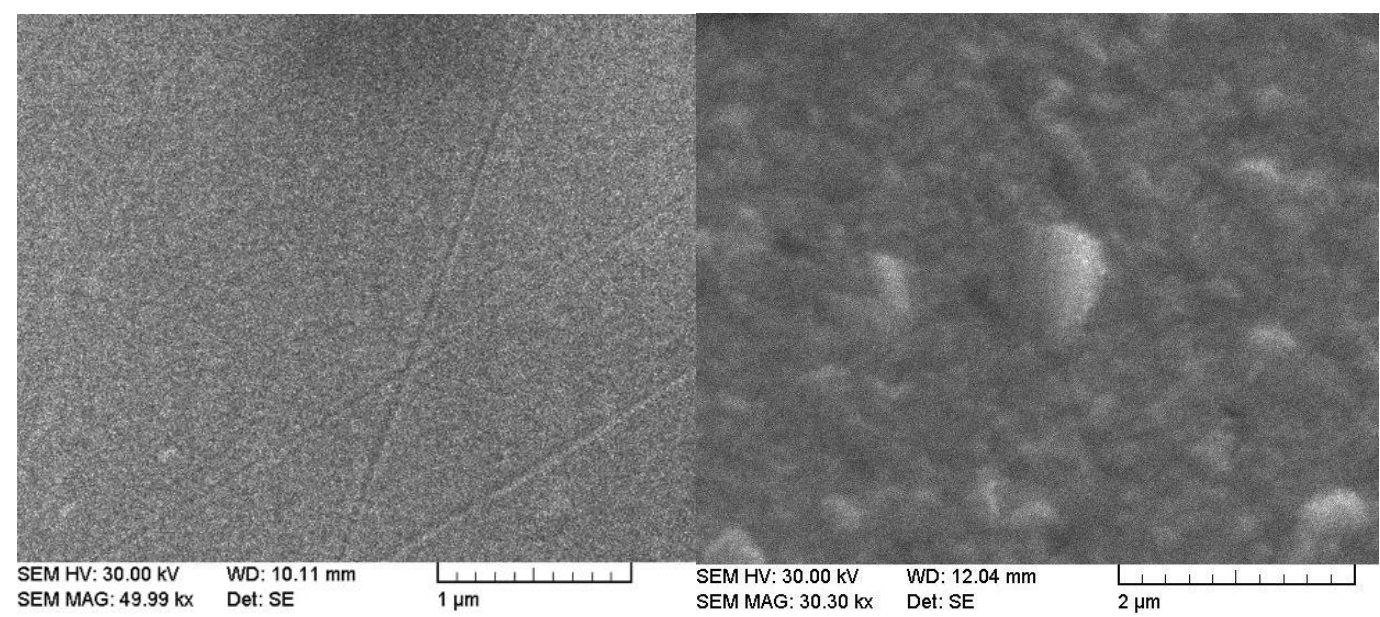

Fig. 2. SEM images of the surface of spinel films deposited at room temperature (a) and at $500^{\circ} \mathrm{C}(\mathrm{b})$.
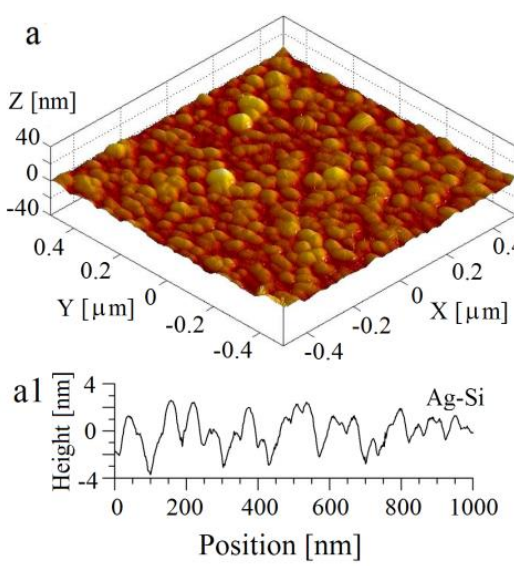
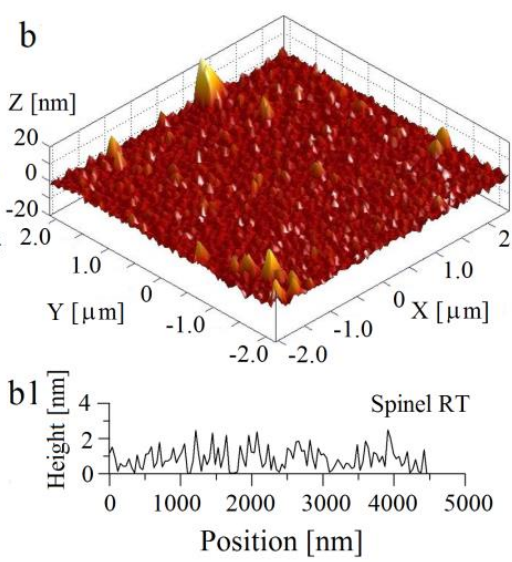

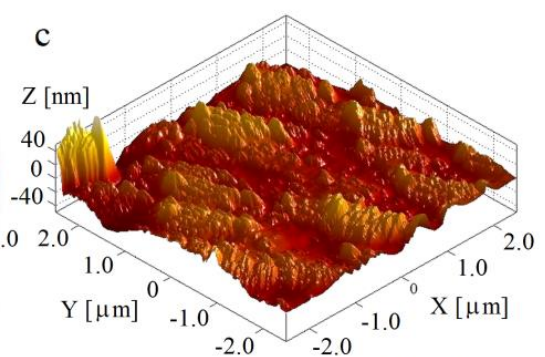

$\mathrm{c}$

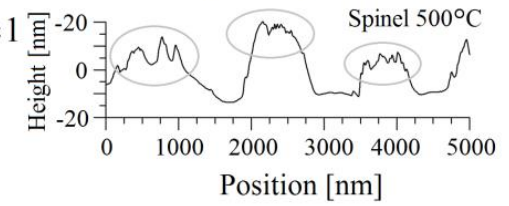

Fig. 3. AFM topography images of the deposited films with the corresponding profiles: a-a1) silver on Si substrate, b-b1) spinel film deposited at RT, c-c1) spinel film deposited at $500^{\circ} \mathrm{C}$.
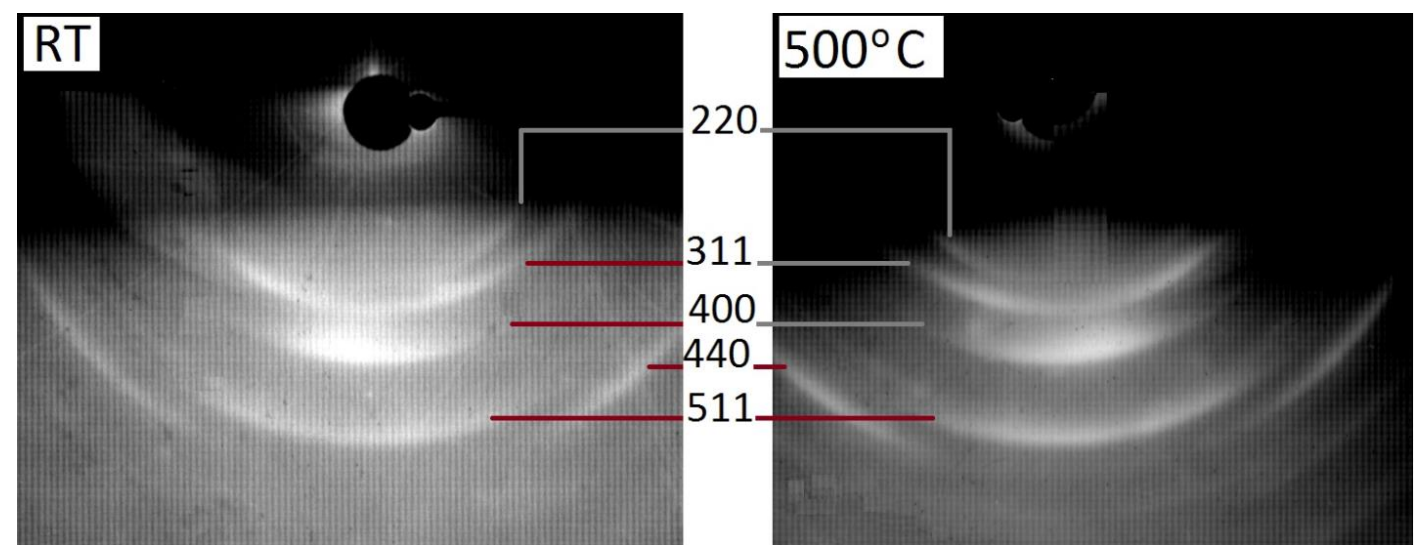

Fig. 4. RHEED pattern of the spinel films deposited at room temperature and at $500{ }^{\circ} \mathrm{C}$.

is composed of homogenous spherical crystallites with diameter between $20-25 \mathrm{~nm}$ and a height a few nanometers, which is confirmed by the profile, Fig $3 \mathrm{a} 1$. The AFM surface topography images of spinel film deposited at room temperature with the corresponding profile are presented on Fig. $3 \mathrm{~b}$ and $3 \mathrm{~b} 1$. The crystallite size is between 120 and $150 \mathrm{~nm}$. The topography of the spinel film deposited at $500^{\circ} \mathrm{C}$, Fig. $3 \mathrm{c}$ is quite different from the film deposited at room temperature, which was already observed by SEM. The corresponding surface profile, presented in Fig 3c1, shows that the film surface is mainly composed of big crystallites, which have a horizontal length of $600-700 \mathrm{~nm}$ and a height from 20 to $30 \mathrm{~nm}$. They are most probably composed of $\mathrm{Mn}_{2} \mathrm{O}_{3}$. On the top of these crystallites, smaller crystallites with sizes from 20 to $50 \mathrm{~nm}$ and a maximum height of $10 \mathrm{~nm}$ are visible, as indicated by ovals in Fig $3 \mathrm{c} 1$. These form the spinel structure. 


\subsection{Reflection High Energy Electron Diffraction (RHEED)}

The electron diffraction patterns obtained from the films are presented in Fig. 4. The patterns are almost identical. On both patterns several bright arcs are clearly visible. The presented patterns show that the samples have a polycrystalline character, but the presence of texture is clearly visible. The calculation of d-distances shows that only the spinel phase is present, Table 1 . No other phases were detected. The lattice constants determined by RHEED patterns are $8.34 \AA$, and 8.28 $\AA$,respectively. The calculated values of the lattice constants are almost the same, as for the target material (difference of $1 \%$ approx.) and correspond well with the one calculated from the XRD diffractogram: $8.367 \AA$.

Table 1

Comparison d-distances calculated from XRD and RHEED patterns for target and spinel films

\begin{tabular}{|c|c|c|c|}
\hline \multirow{2}{*}{} & \multirow{2}{*}{ Target (XRD) } & \multicolumn{2}{|c|}{ RHEED } \\
\cline { 3 - 4 } & & RT & $\mathbf{5 0 0}^{\mathbf{C}} \mathbf{C}$ \\
\hline \hline$h k l$ & $d[\AA]$ & $d[\AA]$ & $d[\AA]$ \\
\hline 111 & 4.836 & & \\
\hline 220 & 2.959 & 2.95 & 2.91 \\
\hline 311 & 2.522 & 2.52 & 2.48 \\
\hline 400 & 2.091 & 2.09 & 2.05 \\
\hline 422 & 1.710 & 1.70 & 1.71 \\
\hline 511 & 1.609 & 1.60 & 1.61 \\
\hline
\end{tabular}

\subsection{Composition measurements (EDS)}

The target composition was measured in the SEM with electron beam acceleration of $20 \mathrm{kV}$, being a typical energy for EDS measurements. However, for films this energy was decreased to $5 \mathrm{kV}$. The excitation depth of the sample material depends on electron energy and can be calculated with Castaing formula:

$$
R=0.033\left(E_{0}^{1.7}-E_{c}^{1.7}\right) \frac{A}{\rho Z}
$$

where: $\mathrm{E}_{0}$ - accelerating voltage, $\mathrm{E}_{\mathrm{c}}-$ minimum emission voltage, $\mathrm{A}-$ atomic mass, $\rho$ - sample density, $\mathrm{Z}$ - atomic number.

Using high electron energy causes excitation not only of the spinel films, but of the substrate as well (Ag film and $\mathrm{Si}$ ). It can cause larger errors in the obtained results and needs the application of a special correction method for obtaining satisfying results $[12,13,14]$. In our case for beam energy of $5 \mathrm{keV}$ the excitation depth is approximately $220 \mathrm{~nm}$ for $\mathrm{Si}$ and $280 \mathrm{~nm}$ for $\mathrm{Ti}$ and for $\mathrm{Mn}$. For comparison, for beam energy of $20 \mathrm{keV}$, the respective depths are between $2.75 \mu \mathrm{m}$ for $\mathrm{Mn}$ and $3.04 \mu \mathrm{m}$ for Si. This means that the excitation depths are comparable or exceeding the films thickness. In this case, the measurements accuracy of the composition the films is smaller compared to measurements in bulk samples.

The compositions of the target and the films are presented in Table 2. Comparison of the results show that the composition of the films and of the target is similar. Magnetron sputtering allows to maintain the composition of the films very close to the one of the target. However, the data presented in Table 2, shows that during the film growth, the oxygen content increases, while the content of all elements decreases. It results from the presence of a higher volume fraction of oxides instead of spinel in the films.

\section{III.Discussion}

Spinel films were deposited by magnetron sputtering by numerous authors. For example, Rufening et. all. [15] deposited pure Mn-Co-Ni-O spinel films on $\mathrm{SiO} / \mathrm{Si}$ substrates at $150{ }^{\circ} \mathrm{C}$. The magnetron power was $4.9 \mathrm{~W} / \mathrm{cm}^{2}$ and the gas pressure was set to $2 \mathrm{~Pa}$. Similar results were presented by Shou et. all [16], who deposited pure spinel films at magnetron power of 2.8$4.3 \mathrm{~W} / \mathrm{cm}^{2}$ at a substrate temperature of $200{ }^{\circ} \mathrm{C}$ and gas pressure of $0.4 \mathrm{~Pa}$. However, the properties of thin films presented in this paper, have a multiphase structure, as well as a nanostructured and hierarchical character.

From the analysis of the obtained results and comparison of properties of the films deposited at different temperatures, we can conclude that independently on the substrate, the films include mainly three oxides: $\mathrm{Mn}_{2} \mathrm{O}_{3}, \mathrm{NiO}$ and $\mathrm{CoO}$. However, the increase of the substrate temperature results in growth of the crystallite size, which is visible in the SEM images in Fig. 2 and in spinel content in the layers, which is visible on XRD diffractograms, Fig. 1.

The crystallites growth during substrate temperature increase, is an effect often observed during film deposition by magnetron sputtering. For example, this is observed in the case of $\mathrm{NiO}$ films [17] and TiN films deposited by magnetron sputtering [18]. The same effect was presented by D. K. Pradkan for spinel ferrite $\mathrm{Ni}_{0.65} \mathrm{Zn}_{0.35} \mathrm{Fe}_{2} \mathrm{O}_{4}$ films deposited by Pulsed Laser Deposition [19] and Prabhu Rajagiri et. all. who deposited $\mathrm{MnFe}_{2} \mathrm{O}_{4}$ spinel films [20]. The authors explain crystallites growth and improving structural quality of the films at higher substrate temperature, as an effect of increasing surface mobility of adatoms on the surface during the film growth. After being ejected from the target, the atoms and ions reach the substrate and, if their energy is adequate, the process of their diffusion over the surface of the substrate begins. The layer grows by adhesion forces or by Van der Vaals forces. The surface

Table 2

Atomic composition spinel target and films with different thickness

\begin{tabular}{|c|c|c|c|c|c|c|c|c|}
\hline $\begin{array}{c}\text { Substrate } \\
\text { Temp. [C] }\end{array}$ & $\begin{array}{c}\text { Thickness } \\
{[\mathrm{nm}]}\end{array}$ & $\mathrm{O}$ & $\mathrm{Al}$ & $\mathrm{Si}$ & $\mathrm{Ti}$ & $\mathrm{Mn}$ & $\mathrm{Co}$ & $\mathrm{Ni}$ \\
\hline & Target & 55.85 & 1.52 & 0.87 & 0.5 & 17.13 & 11.62 & 12.52 \\
\hline $\mathrm{RT}$ & 170 & 61.17 & 1.12 & 0.99 & - & 18.55 & 9.27 & 8.82 \\
\hline $500^{\circ} \mathrm{C}$ & 330 & 59.31 & 1.23 & 1.05 & - & 19.18 & 9.51 & 9.73 \\
\hline
\end{tabular}


of the substrate is not perfectly smooth, there are various types of defects, such as contamination or point defects. Surface irregularities, such as terraces, faults, etc., are also important. They facilitate the binding of diffusing atoms to the substrate and allow the formation of nuclei through which the layers grow. The growth process largely depends on the substrate temperature and the energy of the incident particles. For low temperatures of the substrate, the mobility and average free path are small, which causes the growth of a large number of randomly distributed and oriented islets, combining and forming crystalline grains. Layers deposited at low temperatures are often polycrystalline [21]. Increasing the temperature of the substrate increases the probability of the deposited particles binding with the substrate. Higher initial temperature increases the mobility of the atoms and their free path. If the relation between the substrate energy and the energy of the incoming particles is correct, the atoms at the substrate surface will bond with it, forming nuclei, i.e. points from which the gas phase condensation process begins. At higher temperatures, the nuclei are larger and firmly attached to the substrate, which can force them into a specific orientation, which causes the growth of the textured layers. Under favorable conditions, epitaxial growth is possible. After more atoms are adsorbed to the surface of the substrate, growth takes place, embryos connect and islets are formed, which also grow and connect with each other.

Growth of mixed monoxides films $(\mathrm{CoO}$ and $\mathrm{FeO})$ and spinel was presented by H.Le. Trong et all. [22] during deposition of $\mathrm{Co}_{1.75} \mathrm{Fe}_{1.25} \mathrm{O}_{4}$ spinel films with gas pressure power density $1.3 \mathrm{~W} / \mathrm{cm}^{2}$ and argon pressure $2 \mathrm{~Pa}$. The same effect was observed by B. Mauvernay during deposition of $\mathrm{FeO}-\mathrm{Fe}_{3} \mathrm{O}_{4}$ nanocomposites [23]. For magnetron power density changes in the range 0 $110 \mathrm{~mW} / \mathrm{cm}^{2}$ and argon pressure of $0.5 \mathrm{~Pa}$ different phases: $\mathrm{Fe}_{3} \mathrm{O}_{4}, \mathrm{Fe}_{1-\mathrm{x}} \mathrm{O}$, and $\mathrm{Fe}$ are formed. Deposition of different oxides instead of spinel films was explained as an effect of overheating of the target during sputtering of Ar ions having a high energy and its decomposition. Gambino et. all [24] deposited films with spinel ceramic $\mathrm{Mn}_{1.5} \mathrm{Co}_{1.5} \mathrm{O}_{4}$ target by pulsed laser deposition method. The Authors observed columnar growth and multiphase structure: (Mn, Co)O and pure Co (fcc). The presence of this structure was explained as an effect of reduction of target material at low oxygen pressure and phase transformation during film growth. The Authors show that during film deposition, the temperature and partial pressure of oxygen increase at the deposited surface. This causes a phase transition from a mixture of $(\mathrm{Mn}, \mathrm{Co}) \mathrm{O}+\mathrm{Co}$ to single phase $(\mathrm{Mn}, \mathrm{Co}) \mathrm{O}$. A similar effect i.e. a change of the obtained phase depending of the magnetron power was presented in [25]. When depositing cobalt oxide, the Authors obtained $\mathrm{Co}_{3} \mathrm{O}_{4}$ for low magnetron powers and $\mathrm{CoO}$ for higher ones. For film growth a pure cobalt target was used and the deposition was conducted in $\mathrm{aAr}+\mathrm{O}_{2}$ atmosphere. Simultaneously, the Authors underline, that bombarding the film surface with ions of high energy can cause phase transitions, texturing and stress.

Thermal decomposition of $\mathrm{NiMn}_{2} \mathrm{O}_{4}$ with phase segregation were described by Csete de Györgyfalva et. all [26]. The Authors showed that bulk $\mathrm{NiMn}_{2} \mathrm{O}_{4}$ was decomposed at $907^{\circ} \mathrm{C}$. As a result, they obtained three phases: spinel, spinel type rock salt and cubic NiO. Gaur et. all presented the effect of flash-sintering of $\mathrm{MnCo}_{2} \mathrm{O}_{4}$ powder. For a temperature above $1050{ }^{\circ} \mathrm{C}$ they revealed the presence of cubic $\mathrm{CoO}$ [27]. However, the decomposition of the spinel is possible at high temperature, but in the presented paper this effect was observed at room temperature. This means that magnetron power was sufficient for the decomposition of the spinel films.

The change of the substrate temperature during film growth using magnetron sputtering, was analyzed by Schengyang et. all. [28]. The Authors showed, that during magnetron deposition of the films, a considerable increase in the temperature of the growing films occurs, being a result of the absorption of the heat flux emitted by the target. The real temperature of the film surface measured using an IR camera, was several hundreds of degrees higher, compared to the temperature of the substrate measured using a thermocouple. For example, during the deposition of copper using a heat flux of $0.35 \mathrm{~W} / \mathrm{cm}^{2}$, the temperature of the film surface reached $1000{ }^{\circ} \mathrm{C}$. Similar results were presented in work [29], where during the deposition of $\mathrm{Cr}$ using Ar pressure of $0.2 \mathrm{~Pa}$ and a power of $0.17 \mathrm{~W} / \mathrm{cm}^{2}$, the temperature of the film substrate measured using a thermographic system reached $800^{\circ} \mathrm{C}$, while the one shown by the thermocouple did not exceed $250{ }^{\circ} \mathrm{C}$. The increase of the temperature during deposition considerably influenced the structure of the obtained films.

The process of phase separation during film growth was observed by F. Fritze et. all during deposition of HfNbTiVZr thin films [30]. The Authors observed growth of different phases on different substrate temperatures without annealing, but the substrate temperature was much lower than the temperature of phase separation for bulk samples. The mobility of adatoms on the film surface is much higher than within the bulk sample (of the same type of atoms) at the same temperature. This causes that segregation or formation of a multi-phase structure is possible at lower temperatures during thin film growth than during annealing of a bulk samples.

Although an explanation of the presence of oxide instead of spinel films is possible, however the presence of nanostructured spinel and hierarchical structure mainly on top of the films is not clear. High substrate temperature favors the creation of nanocrystalline hierarchical spinel structure and did not cause spinel decomposition. The formation of a spinel layer on top of the sample surface was presented in [24] as a result of annealing the layer for $0.5 \mathrm{~h}$ at the temperature of $800{ }^{\circ} \mathrm{C}$. Probably a similar process is possible in the presented layers while cooling the layers.

This problem requires additional analysis and measurements.

\section{Conclusions}

Multiphase, hierarchical nanostructures were deposited from monophase spinel target by RF sputtering 
method. The deposited films were composed of three oxides and spinel nanostructure growing mainly on the top the coating. The growth of this structure was an effect of used high magnetron power $\left(8 \mathrm{~W} / \mathrm{cm}^{2}\right)$ what caused phase separation and decomposition of the spinel material during film growth. The increase of the substrate temperature causes a growth of the crystallites size and spinel content in sample.

\section{Acknowledgment}

The authors gratefully acknowledge the use of the services and facilities of the Centre for Interdisciplinary Research of The John Paul II Catholic University of Lublin, Lublin, Poland, co-funded by the European
Union from the European Regional Development Fund in the frame of the Operational Programme Development of Eastern Poland 2007-2013 (POPW.01.03.00-06-003/0900).

The research was performed in the frame of grant Miniatura 1, No. DEC-2017/01/X/ST5/00923 financed by the National Science Center, Poland.

P. Sagan - Ph.D. (physics), assistant;

R. Mroczka - Ph.D. (chemistry), assistant professor;

M. Frugynskyi - M. Sc. (physics) researcher;

G. Wisz - Ph. D (physics), assistant.

[1] K. Ariga, Q. Ji, W. Nakanishi, J.P. Hill, M. Aono, Materials Horizons 2, 406(2015); https://doi.org/10.1039/C5MH00012B.

[2] I. Ashraf, S. Rizwan, M. Iqbal, Front. Mater.7, 181 (2020) ; https://doi.org/10.3389/fmats.2020.00181.

[3] Z. Ren, Y. Guo, C-H. Liu, P-X. Gao, Front. Chem.1, 18 (2013); https://doi.org/10.3389/fchem.2013.00018.

[4] M. Alvarez,A. Calle, J. Tamayo, L.M. Lechuga, A. Abad, and A. Montoya, Biosens. Bioelectron 18, 649 (2003); https://doi.org/10.1016/s0956-5663(03)00035-6.

[5] J. Xu, Z. Pan, S. Peng, Y. Zhao, S. Jiang, Y. Chen, Z-H. Xie, P. Munroe, iScience 24, 101942 (2021); https://doi.org/10.1016/j.isci.2020.101942.

[6] J. Patila, D. Nadargia, I. S.Mullab, S.S. Suryavanshia, Materials Letters 213(15), 27 (2018); https://doi.org/10.1016/j.matlet.2017.11.009.

[7] P. Ma, X. Li, Y, Zhang, Le Han, Yan Xu, Materials Science in Semiconductor Processing 133,105993 (2021); https://doi.org/10.1016/j.mssp.2021.105993.

[8] S. Zhang, W. Jiang, Y. Li, X. Yang, P. Sun, F. Liu, Xu Yan, Y. Gao, X. Liang, J. Ma, G. Lu, Sensors and Actuators B: Chemical 291, 266 (2019); https://doi.org/10.1016/j.snb.2019.04.090.

[9] Qinghong Xu, Yuxue Zhao, Yabo Wei, Wensheng Yang, Feng Li, Mingguang Gu,Solid State Sciences 10(3), 337 (2008); https://doi.org/10.1016/j.solidstatesciences.2007.09.024.

[10] A. Hossain, M.S.I. Sarker, M.K.R. Khan, M.M. Rahman, Materials Science and Engineering: B 253, 114496 (2020); https://doi.org/10.1016/j.mseb.2020.114496.

[11] A. Mahmood, S. M. Ramay, W. Al-Masry, C. W. Dunnil, N. Y. A. Al-Garadi, Journal of Materials Research and Technology 9, 16159 (2020); https://doi.org/10.1016/j.jmrt.2020.11.063.

[12] J.W. Colby, Advances In X-ray Analysis 11, 918 (1968).

[13] L.J. Pouchou, F.Pichoir, Scanning, 12, 212(1990).

[14] G.F. Bastin, J.M. Dijkstra, H.J.M.Heijligers, D.Klepper, Microchimica Acta, 12, 93 (1992); https://doi.org/10.1017/S1431927609991218.

[15] R. Li, Q. Fu, X. Zou, Z. Zheng, W. Luo, L. Yan, Journal of Advanced Ceramics 9(1), 64 (2020); https://doi.org/10.1007/s40145-021-0477-y.

[16] W. Zhou, L. Zhang, Ch. Ouyang, J. Wu, Z. Huang, X-f, Xu, Applied Surface Science 311443 (2014).

[17] M. Kumar, Mater. Res. Express 6,096404 (2019); https://orcid.org/0000-0003-0062-2590.

[18] N. Ghobadi, M. Ganji, C. Luna, A. Arman, A. Ahmadpourian, J Mater Sci: Mater Electron 27, 280019(2016).

[19] D.K. Pradhan, S. Kumari, D.K. Pradhan, A. Kumar, R.S. Katiyar, R.E. Cohen, Journal of Alloys and Compounds766, 1074 (2018); https://doi.org/10.1016/j.jallcom.2018.06.348.

[20] P. Rajagiri, B.N. Sahu,N. Venkataramani, S. Prasad, R. Krishnan, Advances 8, 056112 (2018); https://doi.org/10.1063/1.5007792.

[21] I.O Rudyj, I.V Kurilo, M.S Frugynskyi, M Kuźma, J Zawiślak, I.S Virt, Applied Surface Science 154-155, 206 (2000).

[22] H.Le. Trong, T.M.A. Bui, L. Presmanes, A. Barnabé, I. Pasquet, C. Bonningue, Ph. Tailhades, Thin Solid Films 589, 292 (2015); https://doi.org/10.1016/j.tsf.2015.05.041.

[23] B. Mauvernay, and Presmanes, Lionel and Bonningue, Corine and Tailhades, Philippe, Journal of Magnetism and Magnetic Materials 320 (1), 58 (2008); http://dx.doi.org/10.1016/j.jmmm.2007.05.042.

[24] L.V. Gambino, N.J. Magdefrau, M. Aidnow, Surface and Coatings Technology 286, 206 (2016).

[25] N.F.A. Neto, D.M.G. Leite, P.M. Lisboa-ilho, J.H.D. da Silva, J. Vac, Technol A 36(6), 6152, (2018).

[26] G. De Györgyfalva,\&I. Reaney, Journal of Materials Research18(6), 1301(2003); https://doi.org/10.1557/JMR.2003.0179.

[27] A. Gaur, V.M. Sglavo, Journal of European Ceramic Society 34, 2391(2014). 
[28] L.R. Shaginyan, J.G. Han, V.R. Shaginyan, J. Musil, J. Vac. Sci. Technol. A 24(4), 1083 (2006); https://doi.org/10.1116/1.2210947.

[29] L.R. Shaginyan, V.R. Shaginyan, J.G. Han, Eur. Phys. J. B 46, 335 (2005); https://doi.org/10.1140/epjb/e200500258-4.

[30] S. Fritze, C. M. Koller, Linus von Fieandt, P. Malinovskis, K. Johansson, E. Lewin, P. H. Mayrhofer, U. Jansson, Materials (Basel), 12(4), 587(2019).

П. Саган ${ }^{1}$, М. Фругинський ${ }^{2}$, Р. Мрочка ${ }^{1}, \Gamma$. Віш $^{3}$

\section{Властивості багатокомпонентної (Mn-Ni-Co-Al-Si-Ti) оксид-шпінельної ісрархічно організованої наноструктури, осадженої магнетронним розпиленням при двох температурах}

\footnotetext{
${ }^{1}$ Центр міждисииплінарних досліджень, Люблінський католицький університет імені Яна Павла ІІ, Люблін, Польща, piotr.s.lublin@gmail.com

${ }^{2}$ Національний університет "Львівська політехніка", Львів, Украӥна,

${ }^{3}$ Факультет математики та природничих наук Університету Жешува, Жешув, Польща, gwisz@ur.edu.pl
}

Багатокомпонентні шпінельніплівки наносили на підкладки $\mathrm{Ag} / \mathrm{Si}$ методом магнетронного розпилення. Задавали дві температури підкладки. XRD-вимірювання показують, що шари складаються 3 трьох оксидів металів $\left(\mathrm{Mn}_{2} \mathrm{O}_{3}, \mathrm{NiO}, \mathrm{CoO}\right)$. Наявність шпінельної фази погано візуалізована. Однак, вимірювання дифракції електронів (RHEED) чітко підтвердили наявність наноструктурованої структури шпінелі поверх зразків. Більш того, АCM вимірювання вказують, що на поверхні зразка присутні наноструктуровані острівці шпінелі. Дослідження підтвердилиотримання ієрархічно організованихнаноструктур оксидів шпінелі. Обговорено можливий модельний ріст наноструктур шпінелі при різних температурах.

Ключові слова: магнетронне розпилення, плівки, ієрархічні структури, оксиди шпінелі. 